\title{
SASKATCHEWAN'S FIRST SPECIMEN OF THE BLUE-WINGED WARBLER
}

\author{
by Frank Brazier, Regina
}

On November 9, 1965 while driving to work at $1: 15$ p.m. I noticed a small bird lying on the pavement at 21st Avenue and Elphinstone Street. I was about to dismiss it as another roadkilled House Sparrow when on coming closer I saw its plumage included much yellow. This was long after freeze-up and any bird seen in Regina at that time of year with that much yellow on it would be very strange indeed, so I stopped and picked it up. I saw at once that this was a stranger to me, and having no field guide at hand I could not identify it. Later that day with the help of Robert W. Nero and Robert R. Taylor it was identified as a Blue-winged Warbler (Vermivora pinus). This identification was confirmed by Dr. W. Earl Godfrey of the National Museum of Canada, Ottawa, to whom the specimen was later sent. It is now in the collections of the University of Saskatchewan, Regina Campus.

This was really an astounding record in view of both the normal range of this bird and the lateness of the season. Since one of the nearest points of its normal range is southeast Minnesota, I wrote to Ron Huber of St. Paul for some information; the stomach of our bird contained a great quantity of insects but no eggs or pupa cases as it would have had if it had fed by gleaning, so I also asked Ron about insect life on November 8 . His reply (dated December 6), as usual, was most informative and useful:

"The status here [of the Bluewinged Warbler] has been pretty much the same for many years; it is a yearly breeder in the southeast oneninth of the State . . Minneapolis and St. Paul are just about as far north as the bird gets here. It prefers pseudo-Carolinian habitat and is alway' considered a 'choice' bird since few birders know how to locate it.
This year it did wander westward in our State to Nicollet and Wright counties. There were also more reports than usual of the Golden-winged, and we had an interesting number of reports of hybrids between the two, some verified by photographs ... As for the level of insect activity on Nov. 8-9, there was some. My last butterfly of this year was on Nov. 1... several cold days followed and then another warm period . . . our last moth record was just a few days before Thanksgiving . . . Two days ago, after a movie, my wife and I saw a small yellowish bat flying around downtown for a new late date. It almost looked like a Pipistrelle but they're rare here."

The Regina bird was a male of the year in excellent condition which, for some strange reason, was apparently migrating in the opporite direction to normal. A check with the local meteorological office revealed no strong southeasterly winds at any level; at 3,000 feet there were south winds of three $\mathrm{mph}$ and at 4,000 feet they were southeasterly at six mph. Mr. J. F. Quine advised that these figures would be representative in a radius of 200 miles and for a period of four hours earlier. He added "Further checking shows that there were no really u'seful southerly winds during the previous 24 hours in the area 100 miles to the south of us."

This bird provides Saskatchewan's first specimen of the Blue-winged Warbler, which can now be included in the official list (as a straggler), but it is almost certainly not the first record. On May 19, 1963, Betty and Al Binnie, of the staff of the Provincial Correctional Institution northeast of Regina, examined a similar bird under good conditions, but this sighting has never been published. On the next day (May 20) Betty Cruickshank and Dorothy Wade examined a small 
bird obligingly perched on a fence about 10 miles east of Regina which checked out in every detail with the description of a Blue-winged Warbler but this record likewise was never published.

Spring stragglers are to be expected; for many reasons birds get lost on the spring migration and turn up in the oddest places. But our fall bird was most unusual in that it defies logical explanation--no storm pushed it north, no flocks of migrants were flying north which it might have accompanied. In view of the distance it no doubt travelled (perhaps as much a's 600 miles) and the condition of the stomach contents, one could reasonably guess it had flown steadily northward for many hours, probably overnight since warblers normally migrate at night, and at about 25 mph.

There is one hypothesis which might account for its presence in Regina; it may have become disoriented. Ron Huber states elsewhere in his letter: "Our weather here has been rather strange, warm and cold spells alternating." At Regina we experienced a long open fall caused by a series of low-pressure systems coming from the west, and as these commonly bring much cloudiness far into the interior, our bird could have conceivably started south one night, run into heavy cloud which obscured the stars and ultimately arrived in Regina rather than Central America.

\section{THE 1965 FALL WARBLER MIGRATION AT REGINA}

\section{by Margaret Belcher, Alvin Binnie and Betty Binnie, Regina}

In the Regina area, observers of the 1965 fall migration were struck by the unusual abundance of transient warblers, the number of species represented, and the late dates of departure for some of these.

Ordinarily at Regina, located in the middle of treeless plains, we do not see many warblers. The resident species are limited to the Yellow Warbler and the Yellowthroat, with a single extralimital breeding record of the Myrtle Warbler obtained in the summer of 1965 (Brazier, 1965). During the spring and fall migration there are sometimes conspicuous "waves" of warblers, but in other years the migration season may pass without producing any large numbers. Of the migrants, the Myrtle Warblers are, of course, the most abundant, and they are ordinarily the first to arrive in spring and the last to leave in the fall. On the other hand, species like the Audubon's Warbler, Blackthroated Green, Blackburnian, Chestnut-sided, Bay-breasted, Connecticut, Mourning, and Canada Warbler, have been considered rare or very rare transients, irregular or occasional in their occurrence (Belcher, 1961). This is in spite of the fact that some of these are known to breed farther north in the province-and may even be abundant in their breeding range.

In some cases, the explanation for the scarcity of sight records of the migrant warblers appears to be that the migration passes over Regina without birds stopping here for food and shelter. This is borne out by the counts made in recent years of birds killed at the TV towers. During the first reported fall TV tower kills (Nero, 1961) we were struck by the number of Bay-breasted Warblers (3), which constituted nine per cent of the total count of warblers recovered at the C.KCK-TV tower on September 3, 1961. Two species of warblers considered "rare"" or "very rare" were also present - Mourning Warbler (1) and Connecticut Warbler (1); and a MacGillivray's Warbler provided the first substantiated record of that species for the Regina area. Again on September 10, 1961, two Bay-breasted Warblers were recovered at the CKCK 